\title{
Tanggung Jawab Hukum Perjanjian Asuransi Jiwa Unit Link di PT. Prudential Life Assurance Jakarta
}

\author{
Christine Magdalena Kurniasih Sena ${ }^{*}$, Suherman ${ }^{2}$ \\ ${ }^{1,2}$ Fakultas Hukum Universitas Pembangunan Nasional Veteran Jakarta \\ Jalan Rs. Fatmawati, Pondok Labu, Dki Jakarta, Telp: 07656971 \\ *Correspondence email: kurniasihsena@gmail.com, suherman_upn@yahoo.com
}

\begin{abstract}
Abstrak. Penelitian ini bertujuan untuk mengetahui dan memahami bagaimana tanggung jawab hukum Perusahaan Prudential Life Assurance dalam menjalankan dan memasarkan produk asuransi jiwa berbasis unit link yaitu produk asuransi yang dikaitkan dengan investasi menurut ketentuan perundang-undangan yang berlaku. Disamping itu, penelitian juga bertujuan untuk mengetahui bagaimana tanggung jawab tenaga pemasar yang bertindak untuk dan atas nama perusahaan dalam melakukan perjanjian produk asuransi unit link serta risiko apa saja yang harus ditanggung oleh penanggung maupun tertanggung terhadap perjanjian asuransi jiwa unit link. Penelitian ini menggunakan penelitian hukum yuridis normatif dengan pendekatan perundangundangan serta pendekatan konseptual. Hasil dari penelitian ini adalah bahwa perjanjian asuransi unit link termasuk dalam perjanjian secara umum yang mengandung asas konsensualisme yaitu adanya kesepakatan secara sukarela dalam hal ini untuk mengadakan perjanjian polis asuransi antara penanggung dan tertanggung. Prudential Indonesia dalam memasarkan produk asuransi jiwa unit link juga telah sesuai dengan ketentuan dalam Surat Edaran Otoritas Jasa Keuangan Nomor /SEOJK.05/2019 tentang Produk Asuransi Yang Dikaitkan Dengan Investasi.
\end{abstract}

Kata Kunci: Tanggung Jawab Hukum; Perjanjian Asuransi Jiwa; Unit Link

\begin{abstract}
This study aims to determine and understand how the legal liability of the Prudential Life Assurance Company in carrying out and marketing unit-linked life insurance products, namely insurance products that are linked to investment according to the prevailing laws and regulations. In addition, this study also aims to determine how the responsibility of agent who act for and on behalf of the company in entering into unit-linked insurance product agreements and what risks must be borne by the insurer and the insured against the unit-linked life insurance agreement. This research uses normative legal research with a statutory approach and a conceptual approach. The result of this research is that the unit linked insurance agreement is included in the agreement in general which contains the principle of consensualism, namely the existence of a voluntary agreement in this case to enter into an insurance contract agreement between the insurer and the insured. Prudential Indonesia in marketing unit-linked life insurance products has also complied with the provisions in the Financial Services Authority Circular Letter Number /SEOJK.05/2019 concerning Insurance Products Related to Investment.
\end{abstract}

\section{Keywords: Legal Liability; Life Insurance Contract; Unit Linked}

\section{PENDAHULUAN}

Pasca revolusi industri pada abad pertengahan ke-19, asuransi modern mulai berkembang di Eropa menjadi harapan kehidupan yang baik. Disisi lain, terjadi peningkatan risiko rumah tangga dalam kehidupan industri. Pembangunan bidang prasarana transportasi meningkatkan mobilitas penumpang dari suatu daerah ke daerah bahkan negara lain. Ancaman bahaya lalu lintas juga makin meningkat sehingga kebutuhan perlindungan terhadap barang muatan dan jiwa penumpang juga meningkat. ${ }^{1}$ Pesatnya perdagangan antar bangsa-bangsa mendorong terbentuknya berbagai usaha dagang dalam berbagai bidang sehingga muncul kelompok-kelompok kesatuan modal dalam bentuk usaha-usaha bersama. ${ }^{2}$ Ketidakpastian kehidupan menjadi cikal bakal terjadinya perkumpulan yang bertujuan untuk menanggung risiko bersama akibat perkembangan industrialisasi. Anggota perkumpulan melakukan kesepakatan perjanjian untuk menghimpun iuran dana yang akan diberikan jika ada anggotanya yang mengalami risiko. ${ }^{3}$ Kesepakatan perjanjian anggota perkumpulan yang dibuat pada hakikatnya selalu dilengkapi dengan klausula penerimaan risiko.

Seiring kemajuan industri modern dan ekonomi, perkembangan usaha di bidang perasuransian semakin berdampak positif. Konsep kegiatan perasuransian banyak melahirkan industri perusahaan-perusahaan besar yang bergerak di bidang usaha perasuransian dan diperluas hingga ke berbagai macam jenis risiko pertangunggan dan produk salah satunya asuransi jiwa. Kegiatan usaha asuransi masuk ke bumi nusantara mengikuti keberhasilan bangsa Belanda dalam usaha perkebunan dan perdagangan di negeri jajahannya. Baru kemudian pasca kemerdekaan RI,

\footnotetext{
${ }^{1}$ Abdulkadir Muhammad, Hukum Asuransi Indonesia, (Bandung: Citra Aditya Bakti 2015), hlm. 4.

${ }^{2}$ Sri Rejeki Hartono, Hukum Asuransi Dan Perusahaan Asuransi, (Jakarta: Sinar Grafika 1992), hlm. 39.

3 Hasbullah Thabrany, "Sejarah Asuransi Kesehatan" (Jakarta: Fakultas Kesehatan Masyarakat Universitas Indonesia
} 2010), hlm. 2. 
pemerintah melakukan nasionalisasi atas sejumlah perusahaan asuransi dan untuk pertama kalinya lahir UndangUndang Nomor 2 Tahun 1992 tentang Usaha Perasuransian yang mengatur asuransi sebagai sebuah bisnis. Keberadaan hukum asuransi di Indonesia berakar dari Kodifikasi Hukum Perdata dan Hukum Dagang yang dibawa oleh Belanda dan diatur dalam hukum turunannya yang mengakomodir pekembangan praktik asuransi. ${ }^{4}$

Selain menjadi instrumen yang bertindak sebagai penanggung risiko, industri asuransi juga memiliki peranan penting dalam perkembangan perekonomian Indonesia. Salah satu fungsinya adalah berperan sebagai perencanaan keuangan. Untuk memenuhi kebutuhan masyarakat, industri asuransi jiwa di Indonesia mengembangkan produknya menjadi asuransi yang dikaitkan dengan investasi atau saat ini disebut dengan istilah produk unit link. Produk unit link dapat memberikan solusi yang sesuai dengan kebutuhan masyarakat, sehingga memungkinkan konsumen memperoleh berbagai keuntungan yaitu proteksi dan investasi. Secara teknis, layaknya asuransi pada umumnya, asuransi jiwa unit link tetap memerlukan pembayaran premi secara berkala. Namun perbedaannya adalah asuransi jiwa unit link yang telah dibayarkan sebagai premi dibagi ke dalam dua bagian yaitu: bagian premi khusus untuk manfaat perlindungan dan bagian premi untuk unit investasi. Premi perlindungan berfungsi sama dengan premi pada asuransi biasa atau tradisional yaitu sebagai dana yang disiapkan untuk membayar klaim atas peristiwa yang tak tentun yang dialami oleh nasabah. Sedangkan bagian investasi akan disetorkan oleh perusahaan asuransi kepada manajer investasi untuk dikelola dalam bentuk instrumen penyertaan modal berupa reksa dana, pasar uang, obligasi, dan lain sebagainya. Pada produk-produk tertentu, jika nantinya hasil dari investasi tersebut bisa menutupi biaya premi, maka nasabah memiliki pilihan untuk tidak membayar premi sesuai dengan ketentuan yang tercantum dalam polis asuransi. ${ }^{5}$

Meskipun pada prakteknya asuransi unit link sudah populer dan lama berkembang di Indonesia, namun pada dasarnya produk ini merupakan produk yang lahir setelah terciptanya Undang-Undang Nomor 2 Tahun 1992 tentang Usaha Perasuransian dan tentunya asuransi unit link tidak secara eksplisit disebutkan dalam peraturan ini. Sehingga seiring berjalannya waktu, Undang-Undang Nomor 2 Tahun 1992 dianggap tidak dapat lagi mengakomodir perkembangan produk industri perasuransian di Indonesia. Maka dibuatlah rancangan aturan perundang-undangan yang di dalamnya mengatur lebih lengkap mengenai produk asuransi non-tradisional khususnya produk unit link. Sekitar akhir tahun 2014, terbitlah Undang-Undang Nomor 40 Tahun 2014 Tentang Perasuransian (UU Perasuransian) menggantikan ketentuan yang lama karena mengingat banyaknya perbedaan dan kekurangan terhadap undang-undang sebelumnya yang memerlukan pembahasan khusus terhadap produk asuransi yang baru yang tentunya akan mempengaruhi produk asuransi jiwa unit link secara teoritis maupun praktis.

Salah satu industri asuransi yang memasarkan produk unit link ini adalah PT. Prudential Life Assurance. Perusahaan ini didirikan pada tahun 1995, yang merupakan bagian dari Prudential plc, London, Inggris. Prudential Indonesia juga telah terdaftar serta diawasi oleh Otoritas Jasa Keuangan (OJK). ${ }^{6}$ Pada 1999, Prudential Indonesia sudah menjadi pemimpin pasar sebagai perusahaan asuransi di Indonesia yang pertama kali mengembangkan produk asuransi jiwa unit link yaitu produk yang mempunyai dua manfaat antara lain manfaat asuransi sekaligus manfaat investasi. ${ }^{7}$ Dalam hal ini manfaat yang ditanggungkan kepada perusahaan adalah jiwa dan kesehatan tertanggung sedangkan pada manfaat investasi yaitu pemegang polis dapat memperoleh hasil investasi yang dikelola oleh penanggung dalam hal ini Prudential Indonesia. Pilihan manfaat yang ingin diperoleh kemudian serta besar kecilnya nilai pertanggungan dan nilai investasi dapat ditentukan sendiri oleh calon nasabah/tertanggung pada saat calon nasabah melakukan perjanjian asuransi dengan tenaga pemasar. ${ }^{8}$ Pengertian asuransi sendiri merujuk pada Pasal 1 angka 1 UU Perasuransian, yaitu:

"Asuransi adalah perjanjian antara dua pihak, yaitu perusahaan asuransi dan pemegang polis, yang menjadi dasar bagi penerimaan premi oleh perusahaan asuransi sebagai imbalan untuk:

a. memberikan penggantian kepada tertanggung atau pemegang polis karena kerugian, kerusakan, biaya yang timbul, kehilangan keuntungan, atau tanggung jawab hukum kepada pihak ketiga yang mungkin diderita tertanggung atau pemegang polis karena terjadinya suatu peristiwa yang tidak pasti; atau

b. memberikan pembayaran yang didasarkan pada meninggalnya tertanggung atau pembayaran yang didasarkan pada hidupnya tertanggung dengan manfaat yang besarnya telah ditetapkan dan/atau didasarkan pada hasil pengelolaan dana."

\footnotetext{
${ }^{4}$ Junaedy Ganie, Hukum Asuransi Indonesia, (Jakarta: Sinar Grafika 2011), hlm. 37.

${ }^{5}$ Hening Cipta Putih W. Prayudi, "Perlindungan Hukum Tertanggung Akibat Kegagalan Investasi Yang Dilakukan Perusahaan Asuransi Jiwa Unitlink”, Skripsi thesis, Universitas Airlangga. (Surabaya: Unair, 2015), hlm. 10.

${ }^{6}$ Prudential Indonesia, Materi PRUfast start (Jakarta: Prudential Life Assurance 2014), hlm. 5.

${ }^{7}$ Prudential Indonesia, Ibid.

${ }^{8}$ Nadia Putri, "Tinjauan Yuridis Perjanjian Asuransi Jiwa Dan Unit Link", Skripsi Ilmu Hukum (Surakarta: Fakultas Hukum Universitas Muhammadiyah Surakarta, 2018), hlm. 2.
} 
Berdasarkan pengertian tersebut, maka pengertian asuransi terkandung sebuah perjanjian. Perjanjian yang dilakukan adalah perjanjian asuransi antara tertanggung dalam hal ini adalah pihak yang mengalihkan risiko atau disebut nasabah/pemegang polis dan penanggung risiko yaitu perusahaan asuransi. Perjanjian dilakukan dengan membayar sejumlah premi kepada perusahaan yang nantinya akan menerima manfaat proteksi jika terjadi kerugian atau ketidakpastian. Mengingat arti pentingnya perjanjian dalam asuransi yang tujuannya, yaitu sebagai perjanjian yang memberikan proteksi, maka perjanjian asuransi diadakan dengan maksud memperoleh suatu kepastian atas kembalinya keadaan (ekonomi) sesuai dengan semula sebelum terjadinya peristiwa. ${ }^{9}$

Pada dasarnya produk unit link membutuhkan pemahaman yang memadai oleh calon nasabah yang menggunakannya mengenai risiko dan tanggung jawab dalam hal investasi pada umumnya. Namun yang terjadi dalam masyarakat adalah rendahnya pemahaman terhadap produk asuransi unit link mengenai pengelolaan kinerja dana investasi yang dapat berpotensi menjadi kesalahpamahan dalam pemilihan perencenaan keuangan sebagai investasi yang sesuai dengan kebutuhan pemegang polis. Meskipun pada konsepnya, perjanjian asuransi berarti mengalihkan resiko tertanggung kepada penanggung, tetapi ada juga konsekuensi yang harus disepakati nasabah berkaitan dengan risiko investasi dalam produk unit link. Pertanggungan terhadap risiko yang dilakukan semuanya tentu tertuang dalam perjanjian asuransi yang dibuat antara penanggung dengan tertanggung, yang merupakan bentuk kesepakatan kedua belah pihak pada saat perjanjian asuransi itu dibuat. Hal ini juga tidak menutup kemungkinan jika dalam proses pelaksanaan perjanjian terjadi salah komunikasi antara tenaga pemasar dan calon pemegang polis yang kemudian mengakibatkan salah paham antar keduanya.

Menurut kajian perlindungan konsumen yang dilakukan oleh OJK dewasa ini, bahwa masih banyak pemegang polis yang kemudian mempermasalahkan perjanjian asuransi jiwa unit link yang telah dibuat, dengan alasan antara lain perjanjian cacat hukum karena pemegang polis tidak mengetahui dengan benar baik produknya maupun isi dari perjanjian yang dibuat sehingga tidak merasa wajib untuk mengikutinya. Seperti beberapa aduan kepada Otoritas Jasa Keuangan (OJK) terkait asuransi unit link diantaranya penjelasan asuransi unit link oleh agen yang tidak komprehensif, nasabah belum menerima polis asuransi unit link, dan tindakan fraud yang dilakukan oleh agen serta permasalahan-permasalahan lainnya yang muncul yang akhirnya menjadi sengketa karena suatu ketidakpahaman nasabah secara detil mengenai hak dan kewajiban yang tertera dalam perjanjian polis produk asuransi unit link tersebut. Pemahaman yang salah terhadap asumsi tinggi rendahnya tingkat hasil investasi yang sebenarnya dalam perjanjian polis hanya bertujuan untuk ilustrasi saja dan bukan merupakan tolok ukur untuk perhitungan rata-rata tingkat hasil investasi terendah dan tertinggi membuat pemegang polis kemudian mempermasalahkan nilai investasi yang berbeda dari yang diperjanjikan di awal pembelian polis asuransi unit link. ${ }^{10}$

Berdasarkan pengamatan penulis terhadap penelitian-penelitian terdahulu, belum ada yang meneliti mengenai tanggung jawab hukum perjanjian asuransi jiwa unit link yang dikaitkan dengan peraturan perundang-undangan khusus yang mengatur mengenai pemasaran produk asuransi yang dikaitkan dengan investasi oleh karena peraturan tersebut baru dikeluarkan pada tahun 2019. Sehingga penulis tertarik untuk melakukan penelitian ini dengan rumusan masalah yaitu:

1. Bagaimana tanggung jawab hukum perusahaan dalam melakukan perjanjian asuransi jiwa unit link menurut ketentuan yang berlaku? dan

2. Apakah PT. Prudential Life yang menjalankan produk PAYDI dalam industri usaha asuransi tidak melanggar Peraturan Otoritas Jasa Keuangan yang berlaku?

\section{METODE}

Penelitian ini menggunakan metode penelitian yuridis normatif (legal research) yaitu metode penelitian dengan mengkaji ketentuan-ketentuan dan peraturan perundang-undangan yang terkait dengan hukum asuransi, serta prinsipprinsip dan asas-asas yang terdapat dalam aturan hukum tersebut yang digunakan untuk melihat dan menelaah masalah-masalah yang akan di teliti. Penelitian ini juga dilakukan dengan mengumpulkan data sekunder yaitu jurnaljurnal hukum, teori-teori maupun konsep hukum perjanjian. Penelitian ini menggunakan pendekatan perundangundangan (statute approach) serta menggunakan pendekatan konseptual (conceptual approach).

\section{HASIL DAN PEMBAHASAN}

\section{Tanggung Jawab Hukum Perjanjian Asuransi Jiwa Unit Link di PT. Prudential Life Assurance Jakarta}

Sebelum membahas mengenai tanggung jawab hukum perjanjian asuransi jiwa unit link menurut undangundang, penulis ingin menjelaskan teori tanggung jawab hukum terlebih dahulu menurut pencetus teori hukum murni,

\footnotetext{
${ }^{9}$ Sri Rejeki Hartono, Op. Cit.

${ }^{10}$ Otoritas Jasa Keuangan, “Kajian Perlindungan Konsumen Sektor Jasa Keuangan: Unit Link”, Kajian Otoritas Jasa Keuangan (Jakarta: Departemen Perlindungan Konsumen OJK 2017), hlm. 8.
} 
yaitu Hans Kelsen. Menurut Hans Kelsen: ${ }^{11}$ Sebuah konsep yang berhubungan dengan konsep kewajiban hukum adalah konsep tanggung jawab (pertanggungjawaban) hukum. Bahwa seseorang bertanggungjawab secara hukum atas perbuatan tertentu atau bahwa dia bertanggungjawab atas suatu sanksi bila perbuatannya bertentangan. Biasanya, yakni bila sanksi ditunjukan kepada pelaku langsung, seseorang bertanggungjawab atas perbuatannya sendiri. Dalam kasus ini subjek dari tanggung jawab hukum identik dengan subjek dari kewajiban hukum. Lebih lanjut "Hans Kelsen membagi mengenai tanggungjawab yang terdiri dari: ${ }^{12}$

1. Pertanggungjawaban individu yaitu seorang individu bertanggung jawab terhadap pelanggaran yang dilakukannya sendiri;

2. Pertanggungjawaban kolektif berarti bahwa seorang individu bertanggung jawab atas suatu pelanggaran yang dilakukan oleh orang lain;

3. Pertanggungjawaban berdasarkan kesalahan yang berarti bahwa seorang individu bertanggung jawab atas pelanggaran yang dilakukannya karena sengaja dan diperkirakan dengan tujuan menimbulkan kerugian;

4. Pertanggungjawaban mutlak yang berarti bahwa seorang individu bertanggung jawab atas pelanggaran yang dilakukannya karena tidak sengaja dan tidak diperkirakan."

Tanggung jawab (liability) juga dapat diartikan menurut "Black's Law Dictionary yang mempunyai 3 (tiga) arti, antara lain: ${ }^{13}$

a. Merupakan satu kewajiban terikat dalam hukum atau keadilan untuk melakukan sesuatu;

b. Kondisi menjadi bertanggung jawab atas kerugian atau aktual;

c. Kondisi yang menciptakan tugas untuk melakukan tindakan segera atau di masa depan."

Teori tanggung jawab hukum lebih menekankan pada makna tanggung jawab yang lahir dari ketentuan peraturan perundang-undangan sehingga teori tanggung jawab hukum yang dimaknai sebagai legal liability merupakan konsep yang terkait dengan kewajiban hukum seseorang yang bertanggung jawab secara hukum atas perbuatan tertentu. Tanggung jawab disini merujuk pada tanggung jawab hukum perusahaan asuransi atau subyek hukum sebagai penanggung yang melakukan perjanjian asuransi jiwa berbasis unit link dengan calon tertanggung. Berdasarkan pengertian ini dapat dikatakan bahwa tanggung jawab hukum yang dimaksud adalah kewajiban suatu subyek hukum terhadap segala sesuatu untuk melaksanakan apa yang telah diwajibkan kepadanya. ${ }^{14}$ Dalam hal ini, kewajiban untuk melaksanakan segala sesuatu timbul sebagai akibat dari adanya perjanjian yang telah dibuat antara penanggung dan tertanggung. Sebagaimana yang telah diatur dalam Kitab Undang-Undang Hukum Dagang (KUHD) dan Undang-Undang Perasuransian mengenai asuransi. Pasal 1 angka 1 Undang-Undang No. 40 Tahun 2014 Tentang Perasuransian menyebutkan bahwa:

"Asuransi adalah perjanjian antara dua pihak, yaitu perusahaan asuransi dan pemegang polis, yang menjadi dasar bagi penerimaan premi oleh perusahaan asuransi sebagai imbalan untuk:

a. memberikan penggantian kepada tertanggung atau pemegang polis karena kerugian, kerusakan, biaya yang timbul, kehilangan keuntungan, atau tanggung jawab hukum kepada pihak ketiga yang mungkin diderita tertanggung atau pemegang polis karena terjadinya suatu peristiwa yang tidak pasti; atau

b. memberikan pembayaran yang didasarkan pada meninggalnya tertanggung atau pembayaran yang didasarkan pada hidupnya tertanggung dengan manfaat yang besarnya telah ditetapkan dan/atau didasarkan pada hasil pengelolaan dana."

Dari definisi tersebut, terkandung makna bahwa asuransi berperan sebagai instrumen pengalihan risiko terhadap peristiwa yang tak tentu. Pengalihan risiko ini hanya bisa dilakukan jika penanggung dan tertanggung membuat suatu perjanjian asuransi. Produk asuransi jiwa unit link termasuk ke dalam kategori produk asuransi jiwa. Asuransi jiwa adalah salah satu jenis asuransi sukarela yang dimana asuransi jenis ini terbentuk berdasarkan kehendak bebas para pihak, sehingga perikatan yang ditimbulkan bersumber kepada perjanjian. ${ }^{15}$ Salah satu syarat sahnya sebuah perjanjian menurut Pasal 1320 Kitab Undang-Undang Hukum Perdata (KUHPer) adalah kata sepakat. Kesepakatan dalam perjanjian menganut asas konsensualisme atau kebebasan berkontrak. Sehingga secara normatif, kesepakatan perjanjian asuransi terjadi pada saat penanggung setuju untuk menanggung risiko dari tertanggung dan tertanggung

${ }^{11}$ Hans Kelsen, Pure Theory of Law, Terjemahan Raisul Muttaqien, Teori Hukum Murni: Dasar-Dasar Ilmu Hukum Normatif, Cetakan Ke-6 (Bandung: Nusa Media, 2008), hlm. 136.

${ }^{12}$ Hans Kelsen Terjemahan Raisul Muttaqien, Ibid.

${ }^{13}$ Black's Law Dictionary

${ }^{14}$ Andi Hamzah, Kamus Hukum (Jakarta: Ghalia Indonesia, 2005), hlm. 49.

15 Sastrawidjaja, dkk, Hukum Asuransi: Perlindungan Tertanggung, Asuransi Deposito, Usaha Perasuransian (Bandung: PT. Alumni2013), hlm. 8. 
setuju untuk membayar sejumlah premi tertentu, bahkan menurut Pasal 257 KUHD sebelum polis asuransi ditanda tangani. Kedua belah pihak harus sepakat untuk mengikatkan diri dalam suatu perjanjian berdasarkan persesuaian kehendak. Oleh karena itu, sebuah perjanjian asuransi dipandang sebagai hubungan hukum yang tercipta berdasarkan persesuaian kehendak antara penanggung dan tertanggung secara sukarela. Transaksi inilah yang disebut sebagai pengalihan risiko. ${ }^{16}$ Termasuk dalam perjanjian asuransi yang menggunakan produk asuransi jiwa berbasis unit link atau menurut ketentuan undang-undang dikenal dengan istilah Produk Asuransi Yang Dikaitkan Dengan Investasi (PAYDI). Menurut angka 7 Bab I Surat Edaran OJK No. /SEOJK.05/2019 tentang PAYDI bahwa Produk Asuransi Yang Dikaitkan Dengan Investasi yang selanjutnya disebut PAYDI adalah:

"Produk asuransi yang paling sedikit memberikan perlindungan terhadap risiko kematian dan memberikan manfaat yang mengacu pada hasil investasi dari kumpulan dana yang khusus dibentuk untuk produk asuransi baik yang dinyatakan dalam bentuk unit maupun nonunit, termasuk yang diselenggarakan berdasarkan prinsip syariah."

Oleh karena itu, penanggung dan khususnya tertanggung yang melakukan perjanjian asuransi jiwa unit link dianggap sudah memahami isi perjanjian yang telah dibuat karena telah menyepakati perjanjian tersebut berdasarkan asas konsensualisme. Produk asuransi jiwa unit link yang ditawarkan oleh Perusahaan Prudential Indonesia bernama Pru-link. Prudential Indonesia memasarkan produk asuransi jiwa unit link melalui tenaga pemasar. Dalam hal ini, tenaga pemasar berarti merupakan representasi dari perusahaan sebagai penanggung untuk melakukan perjanjian asuransi jiwa Prulink dengan tertanggung. Dalam perjanjian produk asuransi jiwa unit link diperlukan adanya prinsip itikad baik (utmost good faith) dari perusahaan yang bertanggung jawab untuk memberikan informasi yang benar dan jelas melalui tenaga pemasarnya atas produk yang akan dipasarkan kepada masyarakat sesuai dengan ketentuan dalam Pasal 31 ayat (2) UU Perasuransian yaitu:

"Agen Asuransi, Pialang Asuransi, Pialang Reasuransi, dan Perusahaan Perasuransian wajib memberikan informasi yang benar, tidak palsu, dan/atau tidak menyesatkan kepada Pemegang Polis, Tertanggung, atau Peserta mengenai risiko, manfaat, kewajiban dan pembebanan biaya terkait dengan produk asuransi atau produk asuransi syariah yang ditawarkan."

Produk asuransi jiwa unit link mengandung unsur investasi, maka terdapat risiko investasi yang harus diketahui konsumen. Investasi tidak selamanya membuat dana berkembang, namun ada kalanya dana menjadi menyusut karena hasil investasi menurun. Fluktuasi nilai hasil investasi bergantung dipengaruhi oleh profil risiko investasi yang dipilih sendiri oleh konsumen. Peran edukasi oleh tenaga pemasar atau agen asuransi menjadi sangat krusial, terutama dalam menjelaskan karakteristik produk, manfaat, biaya, risiko investasi dari produk asuransi unit link ini. ${ }^{17}$ Sebagai seorang yang bertindak untuk dan atas nama perusahaan Prudential Indonesia, tenaga pemasar wajib untuk memahami dan menguasai seluk beluk produk asuransi jiwa Prulink. Tanggung jawab Prudential Indonesia melalui para tenaga pemasarnya dalam menerapkan prinsip itikad baik terhadap pemasaran produk asuransi jiwa Prulink kepada masyarakat berpedoman pada ketentuan Bagian C angka 7 Bab VI Surat Edaran OJK No. /SEOJK.05/2019 tentang PAYDI, bahwa:

"Perusahaan memastikan bahwa pemasar yang memasarkan PAYDI telah menjelaskan:

a. PAYDI merupakan produk gabungan antara asuransi dan investasi;

b. risiko investasi pada PAYDI ditanggung oleh pemegang polis;

c. seluruh biaya yang dikenakan kepada pemegang polis antara lain biaya asuransi (Cost of Insurance), management fee, biaya penarikan, biaya pengalihan dana, biaya administrasi, dan biaya lainnya; dan

d. biaya asuransi tambahan/rider (Cost of Rider) yang diambil dari nilai investasi."

Sebagai bentuk tanggung jawab hukum Prudential Indonesia kepada masyarakat, sebelum tenaga pemasarnya melakukan pemasaran produk asuransi jiwa Prulink, semua tenaga pemasar diwajibkan untuk mengikuti program pelatihan wajib secara berkala yang diberikan oleh perusahaan mengenai pengetahuan dan edukasi produk asuransi. Setiap tenaga pemasar akan diberikan materi mengenai produk asuransi jiwa Prulink yang disebut dengan materi Prufast start. Materi ini berfungsi sebagai penunjang calon tenaga pemasar untuk mempermudah mengikuti program pelatihan wajib sesuai dengan Standard Operating Procedure (SOP) yang diterbitkan oleh Prudential Indonesia. ${ }^{18} \mathrm{Hal}$ ini sesuai dengan ketentuan dalam Bagian C angka 4 Bab VI Surat Edaran OJK No. /SEOJK.05/2019 tentang PAYDI mengatur:

"Perusahaan harus memastikan bahwa tenaga pemasar PAYDI memahami PAYDI yang dipasarkan melalui:

a. Penetapan standar pelatihan bagi tenaga pemasar PAYDI; dan

\footnotetext{
${ }^{16}$ Sri Rejeki Hartono, Op. Cit.

17 Otoritas Jasa Keuangan, Ibid.

18 Prudential Indonesia, Ibid.
} 
Christine Magdalena Kurniasih Sena dan Suherman, Tanggung Jawab Hukum Perjanjian Asuransi Jiwa Unit Link Di PT. Prudential Life Assurance Jakarta

b. Pelaksanaan pelatihan mengenai PAYDI yang dipasarkan dan setiap perubahannya yang diselenggarakan oleh internal Perusahaan atau pihak internal."

Lebih lanjut, meskipun tenaga pemasar sudah mengikuti pelatihan wajib yang diadakan oleh perusahaan, tenaga pemasar Prudential Indonesia harus mengikuti ujian lulus sertifikasi keagenan terlebih dahulu untuk dapat memasarkan produk asuransi jiwa unit link sesuai dengan ketentuan dalam Bagian C angka 5 Bab VI Surat Edaran OJK No. /SEOJK.05/2019 tentang PAYDI bahwa:

"Tenaga pemasar PAYDI harus memenuhi ketentuan sebagai berikut:

a. Terdaftar di asosiasi perusahaan perasuransian sesuai dengan bidang usahanya; dan

b. Memiliki sertifikasi keagenan khusus untuk PAYDI dari lembaga sertifikasi profesi di Indonesia sesuai dengan bidang usahanya."

Dilihat dari ketentuan di atas, maka hal ini sudah sesuai dengan prosedur pelaksanaan sertifikasi calon tenaga pemasar yang dilakukan oleh Prudential Indonesia. Sertifikasi khusus pemasaran produk asuransi jiwa Prudential Indonesia telah terdaftar di Asosiasi Asuransi Jiwa Indonesia (AAJI). ${ }^{19}$ AAJI merupakan satu-satunya asosiasi yang mendapat persetujuan tertulis oleh OJK yang memiliki kewenangan untuk menyelenggarakan ujian dan memberikan lisensi bagi tenaga pemasar asuransi jiwa profesional dari seluruh perusahaan anggota di Indonesia. ${ }^{20}$

Tenaga pemasar yang sudah memiliki sertifikasi keagenan, wajib menjunjung tinggi standar praktik dan kode etik yang telah disusun oleh Keputusan RAT AAJI No.02/AAJI/2012 dalam memasarkan produk asuransi jiwa yang dalam hal ini juga termasuk produk asuransi jiwa unit link. Standar kode etik ini antara lain memuat kewajiban tenaga pemasar untuk menjelaskan secara lengkap dan benar kepada calon nasabah asuransi jiwa mengenai profil, kinerja serta produk asuransi jiwa yang dipasarkan. Tenaga pemasar juga berkewajiban untuk memberikan pelayanan terbaiknya bagi calon nasabah. Terhadap agen yang menimbulkan masalah dan melanggar kode etik, maka perusahaan asuransi dapat memberikan sanksi kepada tenaga pemasar berupa: peringatan tertulis kepada agen, rekomendasi penyertaan daftar tenaga pemasar yang bermasalah, usulan pencabutan dan penonaktifan sertifikasi keagenan dari AAJI, dan pengakhiran perjanjian keagenan dari perusahaan. AAJI juga bisa memberikan sanksi berupa pencabutan sertifikasi tenaga pemasar termasuk pencantuman dalam daftar agen bermasalah yang berlaku untuk jangka waktu paling sedikit 5 (lima) tahun.

Dengan demikian, tenaga pemasar Prudential Indonesia yang melakukan pemasaran produk PAYDI sudah sesuai dengan ketentuan perundang-undangan yang berlaku karena telah mengerti dan menguasai produk asuransi jiwa Prulink yang akan ditawarkan kepada tertanggung khususnya produk Prulink yang mempunyai pilihan unit investasi yang cukup beragam. Namun apabila dalam pelaksanaan perjanjian asuransi jiwa Prulink menimbulkan masalah di kemudian hari sehingga menjadi sengketa antara tertanggung dan penanggung, maka menurut Pasal 52 ayat (2) dan (3) Ketentuan Umum Polis Asuransi Prudential Indonesia mengatur bahwa penyelesaian sengketa diluar pengadilan dapat dilakukan melalui proses mediasi atau arbitrase di Lembaga Alternatif Penyelesaian Sengketa atau Badan Mediasi dan Arbitrase Asuransi Indonesia (BMAI) yang ditetapkan oleh OJK. Hal ini sebagai tindak lanjut dari peraturan dalam Pasal 54 UU Perasuransian. Atau jika dalam pelaksanaan melalui jalur mediasi dan arbitrase tidak tercapai, maka para pihak yang berkepentingan atas polis dapat mengajukan penyelesaian persengketaan di Pengadilan Negeri dalam wilayah Republik Indonesia yang berwenang untuk menyelesaikan persengketaan tersebut.

\section{PT. Prudential Life Dalam Menjalankan Produk PAYDI Menurut Peraturan Otoritas Jasa Keuangan}

Produk asuransi jiwa Prulink yang dipasarkan oleh Prudential Indonesia dalam pelaksanaannya mengacu pada ketentuan polis asuransi jiwa unit link yang merupakan kesepakatan antara penanggung dan tertanggung. Sebelum perjanjian polis diterbitkan, Prudential Indonesia akan menyediakan ilustrasi manfaat pertanggungan jiwa dan manfaat investasi yang akan dijelaskan oleh tenaga pemasar sebagai tolok ukur manfaat yang akan diterima oleh tertanggung. Calon tertanggung harus menyetujui ilustrasi manfaat polis asuransi jiwa unit link tersebut sebelum polis diterbitkan. Kewajiban ini telah dilaksanakan Prudential Indonesia seperti yang diatur dalam Bagian C angka 1 Bab II Surat Edaran OJK No. /SEOJK.05/2019 bahwa perusahaan harus memiliki sistem informasi yang memadai untuk mendukung pemasaran produk PAYDI, yaitu minimal mampu memberikan gambaran pertanggungan asuransi atau ilustrasi manfaat yang dibutuhkan kepada calon pemegang polis. Selain itu diatur juga dalam Bagian E angka $1 \mathrm{Bab}$ VI Surat Edaran OJK No. /SEOJK.05/2019, dinyatakan bahwa dalam memasarkan PAYDI, perusahaan harus menyampaikan ringkasan informasi produk kepada calon pemegang polis terlebih dahulu. Prudential Indonesia

${ }^{19}$ AAJI, "Daftar Perusahaan", Asosiasi Asuransi Jiwa Indonesia-AAJI, <https://www.aaji.or.id/Perusahaan/prudential> [accessed 22 January 2021].

${ }^{20}$ AAJI, “Tentang Kami”, Asosiasi Asuransi Jiwa Indonesia-AAJI , <https://www.aaji.or.id/TentangKami/profil-singkat> [accessed 22 January 2021]. 
menerbitkan ringkasan informasi produk dalam bentuk ilustrasi yang disebut dengan ilustrasi Prulink assurance account (PAA). Isi ilustrasi tersebut kurang lebih terdapat 9 hingga 10 halaman yang memuat ringkasan polis manfaat pertanggungan jiwa serta manfaat nilai tunai investasi jangka panjang yang akan diterbitkan dalam bentuk polis jika tertanggung menyetujuinya. Termasuk ilustrasi mengenai ringkasan nilai tunai sebagai skenario manfaat dana investasi yang akan diterima oleh calon tertanggung sebagaimana yang dimuat dalam halaman 4 ilustrasi PAA, menyatakan bahwa asumsi perkiraan tingkat pengembalian investasi yang tinggi dan rendah hanya sebagai gambaran saja dan bukan merupakan patokan untuk menghitung pengembalian investasi rata-rata terendah dan tertinggi.

Kewajiban Prudential Indonesia dalam menyediakan ilustrasi ringkasan polis asuransi jiwa Prulink telah sesuai dengan ketentuan dalam Bagian E angka 2 Bab VI Surat Edaran OJK No. /SEOJK.05/2019 tentang PAYDI. Ringkasan ilustrasi PAA pada halaman 8, Prudential Indonesia juga memuat mengenai "Hal-Hal Penting yang harus diketahui tertanggung dengan poin-poin sebagai berikut:

a. Nomor 1 memuat mengenai ringkasan alokasi premi yang dibentuk ke dalam unit;

b. Nomor 2 memuat mengenai ilustrasi manfaat yang sudah diperhitungkan dengan biaya administrasi sebesar Rp.27.500,-/USD 5 per bulan selama berlakunya asuransi, biaya asuransi yang dikenakan tiap bulan selama berlakunya asuransi, dan biaya pengelolaan investasi per tahun tergantung dari dana investasi yang dipilih;

c. Nomor 5 memuat bahwa asumsi tinggi rendahnya tingkat hasil investasi ini hanya bertujuan untuk ilustrasi saja dan bukan merupakan tolok ukur untuk perhitungan rata-rata tingkat hasil investasi yang terendah dan tertinggi;

d. Nomor 6 memuat jika perubahan harga unit menggambarkan hasil investasi dari dana investasi. Kinerja dari investasi tidak dijamin tergantung dari risiko masing-masing dana investasi. Pemegang polis diberi keleluasaan untuk menempatkan alokasi dana investasi yang memungkinkan optimalisasi tingkat pengembalian investasi, sesuai dengan kebutuhan dan profil risiko Pemegang Polis;

e. Nomor 7 memuat besarnya nilai tunai yang dibayarkan (bisa lebih besar atau lebih kecil dari yang diilustrasikan), akan bergantung pada perkembangan dari dana Investasi Prulink;

f. Nomor 13 memuat besarnya nilai tunai yang terbentuk pada polis ini (dapat lebih besar atau lebih kecil dari dana yang diinvestasikan oleh Pemegang Polis), akan dipengaruhi fluktuasi dari harga unit atau faktor biaya-biaya sebagaimana disebutkan di atas;

g. Nomor 16 memuat bahwa memiliki polis asuransi jiwa merupakan komitmen jangka panjang. Prulink assurance account adalah suatu produk asuransi jiwa yang dikaitkan dengan investasi. Untuk dapat menikmati manfaat polis ini, kami sarankan anda untuk melakukan pembayaran premi selama masa asuransi;

h. Nomor 17 memuat bahwa PT. Prudential Life Assurance terdaftar dan diawasi oleh Otoritas Jasa Keuangan."

Biaya-biaya lainnya yang dibebankan kepada tertanggung diatur lebih lanjut di dalam Bab IX Ketentuan Umum Polis di dalam polis asuransi jiwa Prudential yang akan diterbitkan jika tertanggung sepakat melakukan perjanjian asuransi jiwa Prulink. Selain kewajiban penanggung untuk menjelaskan informasi mengenai produk secara benar dan tepat, Prudential Indonesia dalam memasarkan produknya telah menetapkan prinsip itikad baik yang diwjudkan dengan melengkapi informasi produk mengenai hal-hal yang penting dan jelas seperti yang telah disebutkan di atas melalui ilustrasi PAA sebelum melakukan perjanjian polis asuransi. Hal ini telah sesuai dengan pedoman ketentuan dalam Bagian C angka 7 Bab VI Surat Edaran OJK No. /SEOJK.05/2019. Kemudian dalam hal Prudential Indonesia telah menyetujui pengajuan asuransi jiwa unit link setelah melalui serangkaian tahap proses underwriting dengan mempertimbangkan kriteria calon tertanggung, maka perusahaan akan menerbitkan perjanjian asuransi tersebut berupa polis asuransi jiwa Prulink dan mengirimkannya kepada tertanggung.

Lebih lanjut, pada saat polis asuransi jiwa unit link sudah diterbitkan dan diberikan kepada pemegang polis, masih ada kewajiban perusahaan untuk memastikan bahwa pemegang polis telah memahami produk yang dibeli, termasuk manfaat, risiko dan hal-hal yang perlu diperhatikan dan dipelajari oleh pemegang polis. Ketentuan ini sesuai dengan aturan dalam Bagian B angka 1 Bab III Surat Edaran OJK No. /SEOJK.05/2019 tentang PAYDI yang mengatur:

"Polis Asuransi untuk PAYDI harus memenuhi ketentuan mengenai Polis Asuransi sebagaimana diatur dalam Peraturan Otoritas Jasa Keuangan mengenai Produk Asuransi dan Pemasaran Produk Asuransi, dan paling sedikit memuat ketentuan sebagai berikut:

1. jangka waktu bagi Pemegang Polis untuk mempelajari Polis Asuransi dan Pemegang Polis dapat membatalkan Polis Asuransi dalam jangka waktu tersebut dengan menerima pengembalian Premi atau Kontribusi yang sudah dibayarkan setelah dikurangi biaya administrasi;,"

Sebagai tindak lanjut dari peraturan OJK tersebut, Prudential Indonesia melalui tenaga pemasarnya akan menginformasikan hal tersebut kepada tertanggung setelah polis diterbitkan. Mengenai kewajiban ini telah diatur dalam Pasal 11 Bab IV Ketentuan Umum Polis Asuransi Jiwa Prudential yang diantaranya memuat bahwa dalam 
waktu 14 (empat belas) hari kalender sejak tanggal diterimanya polis, pemegang polis mempunyai waktu untuk mempelajari polis asuransi jiwa Prulink. Jika dalam rentang waktu tersebut pemegang polis tidak setuju dengan ketentuan polis, maka pemegang polis dapat segera memberitahukan kepada penanggung dengan mengembalikan dokumen polis atau dalam hal Polis dibuat dalam bentuk Polis elektronik, maka Pemegang Polis wajib menyerahkan Ringkasan Polis asli. Apabila hal ini terjadi, maka Prudential Indonesia akan memotong biaya yang terkait dengan penerbitan polis (termasuk biaya pemeriksaan kesehatan yang ditentukan oleh perusahaan asuransi, jika ada) dan mengembalikan premi yang telah dibayarkan oleh pemegang polis. Melalui ketentuan ini, pemegang polis Prulink tidak hanya diberikan keleluasaan untuk mempelajari dan mengetahui dengan jelas manfaat produk yang dibeli tetapi juga memahami tentang tanggung jawab baik tertanggung maupun penanggung setelah melakukan perjanjian produk asuransi jiwa Prulink.

\section{SIMPULAN}

Berdasarkan hasil penelitian dan pembahasan yang telah dijelaskan sebelumnya oleh penulis, maka dapat disimpulkan pertama, bahwa perjanjian asuransi jiwa unit link pada prinsipnya sama dengan perjanjian pada umumnya yang tidak terlepas dari ketentuan yang berlaku dalam Pasal 1320 KUHPer. Dibutuhkan adanya kesepakatan secara sukarela antara pihak penanggung dan tertanggung dalam melaksanakan perjanjian berdasarkan asas konsensualisme. Atas dasar kesepakatan tersebut, maka timbul kewajiban yang harus dipenuhi oleh perusahaan dalam melaksanakan perjanjian asuransi jiwa unit link. Prudential Indonesia dalam memasarkan produk asuransi jiwa Prulink melalui tenaga pemasarnya menerapkan prinsip itikad baik sebagai tanggung jawab hukum perusahaan dalam memasarkan produknya yang berpedoman dalam ketentuan dalam Undang-Undang Nomor 40 Tahun 2014 tentang Perasuransian. Prudential Indonesia juga mengatur upaya alternatif penyelesaian sengketa melalui jalur arbitrase maupun gugatan ke pengadilan negeri apabila timbul masalah dalam pelaksanaan perjanjian asuransi Prulink di kemudian hari.

Kedua, sebagai tindak lanjut terhadap pelaksanaan pemasaran produk Prulink, Prudential Indonesia berpedoman kepada peraturan dalam Surat Edaran Otoritas Jasa Keuangan No. /SEOJK.05/2019 yang khusus mengatur mengenai Produk Asuransi Yang Dikaitkan Dengan Investasi (PAYDI). Kewajiban perusahaan dalam perjanjian asuransi PAYDI harus dilakukan melalui persetujuan atas ringkasan manfaat polis atau ilustrasi terlebih dahulu. Termasuk halhal mengenai unsur investasi dan biaya-biaya yang akan menjadi tanggung jawab tertanggung. Sehingga dengan begitu, tertanggung dapat mengetahui dengan benar dan jelas bagaimana risiko dan manfaat yang akan diterima oleh tertanggung maupun penanggung dalam perjanjian asuransi jiwa Prulink.

\section{DAFTAR PUSTAKA \\ Buku}

Hamzah, Andi. Kamus Hukum, Jakarta: Ghalia Indonesia, 2005.

Hartono, Sri Rejeki. Hukum Asuransi Dan Perusahaan Asuransi. Jakarta: Sinar Grafika, 1992.

Hasbullah, Thabrany. Sejarah Asuransi Kesehatan. Jakarta: Fakultas Kesehatan Masyarakat Universitas Indonesia, 2010.

Junaedy, Ganie. Hukum Asuransi Indonesia. Jakarta: Sinar Grafika, 2011.

Kelsen, Hans. Pure Theory of Law (Terjemahan Raisul Muttaqien Teori Hukum Murni:Dasar-Dasar Ilmu Hukum Normatif). Bandung: Nusa Media, 2008.

Muhammad, Abdulkadir. Hukum Asuransi Indonesia. Bandung: Citra Aditya Bakti, 2015.

Marzuki, Peter Mahmud. Penelitian Hukum. Jakarta: Kencana, 2015.

Sastrawidjaja, dkk. Hukum Asuransi: Perlindungan Tertanggung, Asuransi Deposito, Usaha Perasuransian. Bandung: PT. Alumni, 2013.

\section{Perundang-undangan}

Republik Indonesia, Kitab Undang-Undang Hukum Dagang (KUHD).

Republik Indonesia, Kitab Undang-Undang Hukum Perdata (KUHPer).

Republik Indonesia, Undang-Undang Nomor 2 Tahun 1992 Tentang Usaha Perasuransian.

Republik Indonesia, Undang-Undang Republik Indonesia Nomor 40 Tahun 2014 Tentang Perasuransian.

Republik Indonesia, Undang-undang Nomor 21 Tahun 2011 tentang Otoritas Jasa Keuangan.

Republik Indonesia, Peraturan Pemerintah Nomor 73 Tahun 1992 Tentang Penyelenggaraan Usaha Asuransi.

Republik Indonesia, Surat Edaran Otoritas Jasa Keuangan Nomor /SEOJK.05/2019 Tentang Produk Asuransi Yang Dikaitkan Dengan Investasi. 
Christine Magdalena Kurniasih Sena dan Suherman, Tanggung Jawab Hukum Perjanjian Asuransi Jiwa Unit Link Di PT. Prudential Life Assurance Jakarta

\section{Buku Pedoman, Makalah, Artikel, Jurnal dan Surat Kabar}

Otoritas Jasa Keuangan. Kajian Perlindungan Konsumen Sektor Jasa Keuangan: Unit Link. Jakarta: Departemen Perlindungan Konsumen OJK 2017

Prayudi, Hening Cipta Putih W. Perlindungan Hukum Tertanggung Akibat Kegagalan Investasi Yang Dilakukan Perusahaan Asuransi Jiwa Unit Link. Surabaya: Fakultas Hukum Universitas Airlangga, 2015.

Putri, Nadia. Tinjauan Yuridis Perjanjian Asuransi Jiwa Dan Unit Link. Surakarta: Fakultas Hukum Universitas Muhammadiyah Surakarta, 2018.

Prudential Indonesia. Materi PRUfast start. Jakarta: Prudential Life Assurance, 2014.

Black's Law Dictionary.

\section{Website}

https://aaji.or.id/ diakses pada tanggal 22 Januari 2021. 